\title{
Growth and gas changes of melon seedlings submitted to water salinity
}

\author{
Valéria F. de O. Sousa ${ }^{1}$, Caciana C. Costa ${ }^{2}$, Genilson L. Diniz ${ }^{3}$, \\ João B. dos Santos², Marinês P. Bomfim² \& Kilson P. Lopes² \\ ${ }^{1}$ Universidade Federal de Campina Grande/Centro de Ciências e Tecnologia Agroalimentar/Programa de Pós-Graduação em Horticultura Tropical. \\ Pombal, PB. E-mail: valeriafernandesbds@gmail.com - ORCID: 0000-0002-6124-0898 \\ ${ }^{2}$ Universidade Federal de Campina Grande/Centro de Ciências e Tecnologia Agroalimentar/Unidade Acadêmica de Ciências Agrárias. Pombal, PB. \\ E-mail: costacc@ccta.ufcg.edu.br (Corresponding author) - ORCID: 0000-0003-2598-466X; agrosantos@hotmail.com - ORCID: 0000-0003-3058-007X; \\ mpbfito@gmail.com - ORCID: 0000-0003-2424-3843; kilsonlopes@gmail.com - ORCID: 0000-0003-1577-5901 \\ ${ }^{3}$ Universidade Federal de Campina Grande/Centro de Ciências e Tecnologia Agroalimentar/Programa de Ensino Tutorial - Agronomia. Pombal, PB. \\ E-mail: genilsondiniz02@hotmail.com - ORCID: 0000-0002-2503-6080
}

\begin{abstract}
The melon is an outstanding fruit crop in Brazil, mainly in the Northeast region due to favorable conditions for cultivation. Water salinity affects the growth and production of several species, but there is tolerance among cultivars of the same species. The objective of this study was to evaluate the growth and gas exchange in melon seedlings subjected to water salinity. Experiment was carried out in a greenhouse belonging to the Center of Sciences and Agri-Food Technology, Federal University of Campina Grande, Pombal, PB, Brazil, from September to October 2016. The experimental design was a randomized complete block design in a $6 \times 5$ factorial scheme, with four replicates, for six cultivars of melon (Natal, Solares, Goldex, Iracema, Mandacaru and Amarelo Ouro) and five irrigation water salinity levels with the following electrical conductivities: $0.3,1.1,1.9,2.7$ and $3.5 \mathrm{dS} \mathrm{m}^{-1}$. Each experimental unit consisted of a polypropylene container with a volume capacity of $0.350 \mathrm{dm}^{3}$, which contained soil + Basaplant ${ }^{\circledast}$ commercial substrate at a ratio of 2:1. At 25 days after sowing, the plants were evaluated for growth, gas exchange and dry mass accumulation. Increased salinity of irrigation water inhibits the growth, dry mass accumulation and physiological processes of melon cultivars. The cultivar Natal showed to be more tolerant, while the cultivars Solares, Goldex, Iracema and Mandacaru were moderately sensitive and the cultivar Amarelo Ouro was more sensitive to the salinity of irrigation water.
\end{abstract}

Key words: Cucumis melo L., cultivars, physiology

\section{Crescimento e trocas gasosas de mudas de meloeiro submetidas à salinidade da água}

RESUMO: O meloeiro é uma olerícola de destaque no Brasil, principalmente no Nordeste pelas condições edafoclimaticas favoráveis para cultivo. A salinidade da água acomete o crescimento e produção de diversas espécies, porém há tolerância entre cultivares de uma mesma espécie. Com isso, objetivou-se estudar o crescimento e as trocas gasosas em mudas de meloeiro submetidas à salinidade da água. Foi desenvolvido experimento em casa de vegetação pertencente ao Centro de Ciências e Tecnologia Agroalimentar, Universidade Federal de Campina Grande, município de Pombal, PB, no período de setembro a outubro de 2016. O delineamento experimental utilizado foi em blocos casualizados em esquema fatorial $6 \times 5$, com quatro repetições, relativo a seis cultivares de meloeiro (Natal, Solares, Goldex, Iracema, Mandacaru e Amarelo Ouro) e cinco níveis de salinidade da água de irrigação, com as seguintes condutividades elétricas: 0,$3 ; 1,1 ; 1,9 ; 2,7$ e $3,5 \mathrm{dS} \mathrm{m}^{-1}$. Cada unidade experimental foi constituída de um recipiente de polipropileno com capacidade volumétrica de $0,350 \mathrm{dm}^{3}$, no qual foram acondicionados solo + substrato comercial Basaplant ${ }^{\oplus}$ na proporção de 2:1. Aos 25 dias após a semeadura as plantas foram avaliadas quanto ao crescimento, trocas gasosas e acúmulo de massa seca. O aumento da salinidade da água de irrigação inibe o crescimento, acúmulo de massa seca e os processos fisiológicos dos cultivares de meloeiro. O cultivar Natal demonstrou ser mais tolerante, enquanto os cultivares Solares, Goldex, Iracema e Mandacaru demonstraram moderadamente sensíveis e o cultivar Amarelo Ouro mais sensível a salinidade da água de irrigação.

Palavras-chave: Cucumis melo L., cultivares, fisiologia 


\section{INTRODUCTION}

Melon (Cucumis melo L.) is a profitable crop with fast economic return, besides being adapted to the Northeast region. The Brazilian production, according to the data of IBGE (2017), was 873,196 tons of melon fruits and the Northeast region is the largest producer, with $94 \%$, mainly the state of Rio Grande do Norte (642,306 tons) with cultivation concentrated in the microregion of Mossoró, specifically at the Apodi Plateau, encompassing the semi-arid region close to the coast (Pereira et al., 2017).

However, the parent material, irregular rainfalls and high temperatures in this region have caused salinization of water and soil in areas of melon production (Medeiros et al., 2012). Excess salts harm soil fertility because they affect the availability of beneficial ions such as calcium and potassium to plants (Lima et al., 2018; Sá et al., 2018). Daily application of water with high contents of salts in irrigation compromises growth, development, and consequently the production of various cucurbits, including Curcubita moscata (Carmo et al., 2011), Citrullus lanatus (Costa et al., 2013; Silva et al., 2015) and Cucumis melo (Freitas et al., 2014).

Adversities occur because excess salts in the water cause negative effects on plants, such as reduction in water availability, i.e., osmotic effect, nutritional imbalance and toxicity by specific ions, especially sodium $\left(\mathrm{Na}^{+}\right)$and chlorine $(\mathrm{Cl})$ at high concentrations, which compromise morphological and physiological performances, as observed by Bosco et al. (2009) and Carmo et al. (2011) in eggplant (Solanum melongena) and pumpkin (Curcubita moscata) and by Araújo et al. (2016) in melon cultivars.

However, tolerance to salinity differs among species and cultivars of a same species (Aragão et al., 2009; Araújo et al., 2016). Pereira et al. (2017), who studied five melon cultivars: Sancho, Medellín, Mandacaru, Néctar and Sedna, found that the cultivar Sancho was more tolerant to the salt, followed by Mandacaru, Medellín, Sedna and Néctar.

Therefore, with the appearance of new cultivars and due to the scarce information related to the effects of salts on physiological aspects in melon cultivars, the present study aimed to evaluate the growth and gas exchanges in seedlings of melon cultivars subjected to water salinity.

\section{Material ANd Methods}

The experiment was conducted from September to October 2016 in a greenhouse at the Federal University of Campina
Grande (UFCG) in the Center of Sciences and Agri-Food Technology (CCTA), located in the municipality of Pombal, Paraíba, Brazil. This municipality is situated in the western region of the Paraíba state, at geographic coordinates $6^{\circ} 46^{\prime} 12^{\prime \prime} \mathrm{S}, 37^{\circ} 48^{\prime} 07^{\prime \prime} \mathrm{W}$ and altitude of $184 \mathrm{~m}$. According to Köppen's classification, the climate of the region is BSh, which indicates a hot and dry semi-arid climate, with mean rainfall of approximately $750 \mathrm{~mm}$ year $^{-1}$, and mean annual evapotranspiration of 2,000 $\mathrm{mm}$ (Alvares et al., 2013).

The experiment was set up in a $6 \times 5$ factorial scheme and treatments were arranged in randomized blocks, with four replicates and two plants per plot. The sources of variation corresponded to six cultivars of melon - Cucumis melo (cv. Natal, cv. Solares, cv. Goldex, cv. Iracema, cv. Mandacaru and $\mathrm{cv}$. Amarelo Ouro) and five levels of irrigation water electrical conductivity $\left(0.3 ; 1.1 ; 1.9 ; 2.7 ; 3.5 \mathrm{dS} \mathrm{m}^{-1}\right)$.

The substrate was composed of soil and Basaplant (based on pine bark, peat, charcoal, vermiculite, initial fertilization with NPK and micronutrients) at 2:1 proportion, respectively, placed in $0.35 \mathrm{dm}^{3}$ dark polypropylene containers. The soil used was autoclaved at temperature of $121^{\circ} \mathrm{C}$ for $1 \mathrm{~h}$. The physical and chemical characteristics of soil and commercial substrate (Table 1) were determined at the Laboratory of Soils and Plant Nutrition of the UFCG, according to methodologies proposed by Donagema et al. (2011).

Two seeds were planted at $0.02 \mathrm{~m}$ depth in each container and, seven days after sowing (DAS), thinning was performed leaving only the most vigorous seedling.

Waters of increasing salinity were prepared by diluting noniodized sodium chloride ( $100 \%$ pure) in water from the local supply company (CAGEPA), chemical characteristics described in Table 2, using Eq. 1 according to Rhoades et al. (2000), and measuring later for simple confirmation with a portable digital conductivity meter (model TSD \& EC).

$$
\mathrm{Q}=\mathrm{ECW} 640
$$

where:

Q - quantity of $\mathrm{NaCl}$ added to the water, $\mathrm{mg} \mathrm{L}^{-1}$; and,

$\mathrm{ECw}$ - desired level of water electrical conductivity, dS $\mathrm{m}^{-1}$

Irrigations were applied once a day to increase soil moisture to close to field capacity, based on the drainage lysimetry method, and a leaching fraction of 0.20 was added to the applied water depth. The volume applied (Va) per container was obtained by the difference between the previous water

Table 1. Physical and chemical attributes of the components of the substrate (soil and Basaplant ${ }^{\circledR}$ commercial substrate) used in melon cultivation

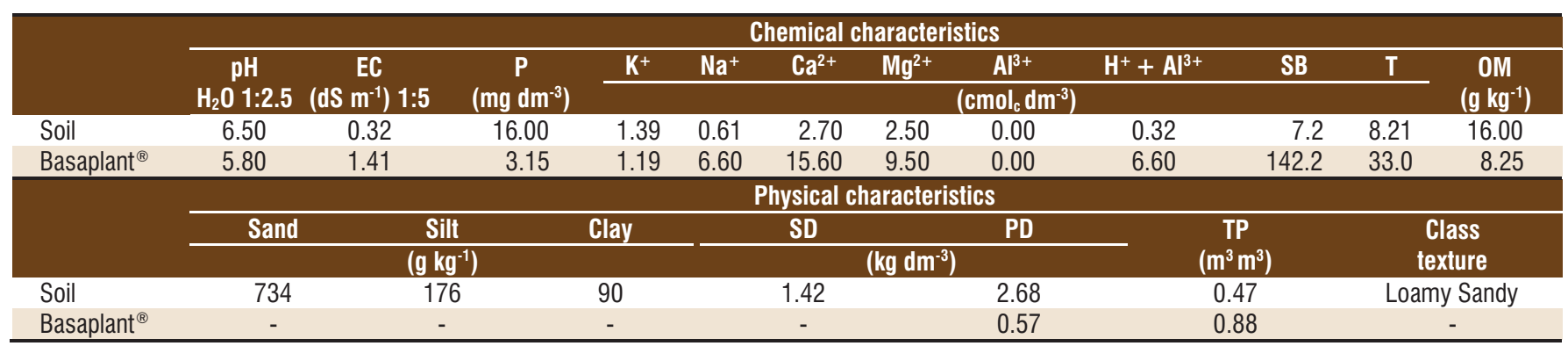

SB - Sum of bases; EC - Electrical conductivity; T - Total cation exchange capacity; OM - Organic matter; DS - Soil Density; PD - Particle Density; TP- Total Porosity 
Table 2. Chemical analysis of the public-supply water used to prepare the solutions

\begin{tabular}{|c|c|c|c|c|c|c|c|c|c|c|c|}
\hline \multirow[t]{2}{*}{ Water } & $\begin{array}{c}E_{\mathrm{w}} \\
\left(\mathrm{dS} \mathrm{m}^{-1}\right)\end{array}$ & $\mathrm{pH}$ & $\mathbf{K}^{+}$ & $\mathrm{Ca}^{2+}$ & $\mathrm{Mg}^{2+}$ & $\frac{\mathrm{Na}^{+}}{\mathrm{mol}_{\mathrm{c}} \mathrm{t}}$ & $\mathrm{SO}_{4}^{-2}$ & $\mathrm{CO}_{3}{ }^{-2}$ & $\mathrm{HCO}_{3}{ }^{-}$ & $\mathrm{Cl}^{-}$ & \multirow{2}{*}{$\begin{array}{c}\text { SAR } \\
\left(\mathrm{mmol} \mathrm{L}^{-1}\right)^{0.5}\end{array}$} \\
\hline & 0.3 & 7.0 & 0.3 & 0.2 & 0.6 & 1.4 & 0.2 & 0.0 & 0.8 & 1.3 & \\
\hline
\end{tabular}

Note: ${ }^{1} \mathrm{EC}_{\mathrm{w}}$ - Electrical conductivity of water; SAR - Sodium adsorption ratio

depth (La) applied minus the average drainage (D), divided by the number of containers $(\mathrm{N})$, divided by one, minus the leaching fraction (LF), according to Eq. 2.

$$
\mathrm{Va}=\frac{\mathrm{La}-\left(\frac{\mathrm{D}}{\mathrm{N}}\right)}{(1-\mathrm{LF})}
$$

At 25 DAS, phenological analyses were conducted based on main stem length, measured with a ruler, considering the distance between soil and plant apex, and leaf area (LA), determined by measuring the width of leaves, according to Eq. 3 of Nascimento et al. (2002).

$$
\mathrm{LA}=0.826 \mathrm{~W}^{1.89}
$$

where:

LA - leaf area; and,

W - width of leaves.

At the same age, readings of $\mathrm{CO}_{2}$ assimilation (A), transpiration (E), intercellular $\mathrm{CO}_{2}$ concentration $\left(\mathrm{C}_{\mathrm{I}}\right)$ and stomatal conductance (gs) were taken with the portable photosynthesis meter "LCPro+" of ADC BioScientific Ltda, in the third fully expanded leaf subjected to saturating irradiance $\left(1000 \mu \mathrm{mol} \mathrm{m}^{-2} \mathrm{~s}^{-1}\right)$.

After the readings, plants were removed from the substrate, separated into roots and shoots, and dried in forced air circulation oven at $65{ }^{\circ} \mathrm{C}$ until constant weight, to obtain shoot dry mass and root dry mass. These masses partitioned among vegetative organs were summed to obtain the total dry mass (TDM) and calculate the salinity tolerance index (STI), by comparing the data of saline treatments with those of the control $\left(\mathrm{ECw}=0.3 \mathrm{dS} \mathrm{m}^{-1}\right)$, using Eq. 4 .

$\mathrm{STI}=\frac{\text { TDM production in the saline treatment }}{\text { TDM production in the control treatment }} \times 100$

In which the STI considers the electrical conductivity corresponding to the relative efficiency of $75 \%$.

The data were subjected to analysis of variance; means among cultivars were compared by Scott-Knott test and those relative to water salinity were compared by regression, using the software SISVAR Version 5.6 (Ferreira, 2011).

\section{Results AND Discussion}

The interaction between cultivars and water salinity levels had significant effects $(p>0.05)$ on all variables of biometric growth, physiological aspects and biomass formation by roots and shoots in the production of melon seedlings, corroborating some authors who worked with irrigation water salinity and melon cultivars (Aragão et al., 2009; Lúcio et al., 2013; Araújo et al., 2016; Lopes et al., 2017; Pereira et al., 2017).
The data of net $\mathrm{CO}_{2}$ assimilation of the cultivars Amarelo Ouro and Solares did not fit to any mathematical model with the increase in water salinity and were represented by the mean values of 3.42 and $2.13 \mu \mathrm{mol} \mathrm{m} \mathrm{m}^{-2} \mathrm{~s}^{-1}$ (Figure 1A). Increasing water salinity inhibited the net $\mathrm{CO}_{2}$ assimilation of the cultivars Goldex (42.94\%), Iracema (52.98\%) and Mandacaru (53.12\%) and stimulated it up to the highest value of $5.49 \mu \mathrm{mol} \mathrm{m}^{-2} \mathrm{~s}^{-1}$ in plants of the cultivar Natal irrigated using waters with maximum estimated electrical conductivity of $1.1 \mathrm{dS} \mathrm{m}^{-1}$; comparatively, the cultivar Natal was shown to be less sensitive to salinity.

Net $\mathrm{CO}_{2}$ assimilation is related to stomatal conductance, since greater stomatal opening favors higher influx of carbon dioxide in leaf mesophyll, increasing its internal concentration and consequently, increasing photosynthesis (Taiz et al., 2017). The divergence in the physiological behavior of the cultivars was also found by Akrami \& Arzani (2018), when analyzing the interference of salinity on physiology in other 17 other cultivars of melon. Morais et al. (2018), in melon plants cv. AF 015 under irrigation with saline nutrient solutions, found highest photosynthetic rate estimated for the lowest level of salinity $\left(1.1 \mathrm{dS} \mathrm{m}^{-1}\right)$, whereas the lowest photosynthetic rate was observed at the highest level of salinity $\left(5.5 \mathrm{dS} \mathrm{m}^{-1}\right)$.

For stomatal conductance (gs), the cultivars Iracema and Amarelo Ouro did not fit to any mathematical model for regression, showing the respective mean values of 0.05 and $0.03 \mathrm{~mol} \mathrm{~m}^{-2} \mathrm{~s}^{-1} \mathrm{H}_{2} \mathrm{O}$ (Figure $1 \mathrm{~B}$ ). The cultivar Natal stood out with the highest value at estimated electrical conductivity of $1.3 \mathrm{dS} \mathrm{m}^{-1}\left(0.0723 \mathrm{~mol} \mathrm{~m}^{-2} \mathrm{~s}^{-1}\right)$, whereas the cultivars Solares, Goldex and Mandacaru reached it at the respective levels of 1.7, $1.5,1.6 \mathrm{dS} \mathrm{m}^{-1}\left(0.05205 ; 0.05567 ; 0.0612 \mathrm{~mol} \mathrm{~m}^{-2} \mathrm{~s}^{-1}\right)$. According to Arantes et al. (2016), the difference in the physiological behavior of cultivars is due to a genotypic variation in response to the environment, which may select cultivars that are superior to the others.

The reduction in gs in seedlings irrigated using water above $1.3 \mathrm{dS} \mathrm{m}^{-1}$ can be explained because the accumulation of salts in the substrate reduces water availability, causing decrease in leaf water potential, leading to loss of turgor and reduction in stomatal conductance (Bosco et al., 2009). Thus, the increment of salts from higher concentrations in irrigation water reduces $\mathrm{CO}_{2}$ assimilation and, consequently, stomatal conductance, due to photochemical damages caused by the decrease in stomatal opening (Freire et al., 2014).

The transpiration of melon seedlings in the cultivars Solares and Iracema, despite not fitting to the regression model, showed means of 1.44 and $1.75 \mathrm{mmol} \mathrm{m}^{-2} \mathrm{~s}^{-1}$, respectively (Figure 1C). The cultivars Goldex and Mandacaru exhibited increases of 19.88 and $48.76 \%$, respectively at the levels from 0.3 to 1.5 and from 0.3 to $2 \mathrm{dS} \mathrm{m}^{-1}$, decreasing from these levels on. The cultivars Natal and Amarelo Ouro linearly reduced their transpiration rates by 47.92 and $66.28 \%$, respectively, between seedlings irrigated using waters of highest and lowest salinity. 

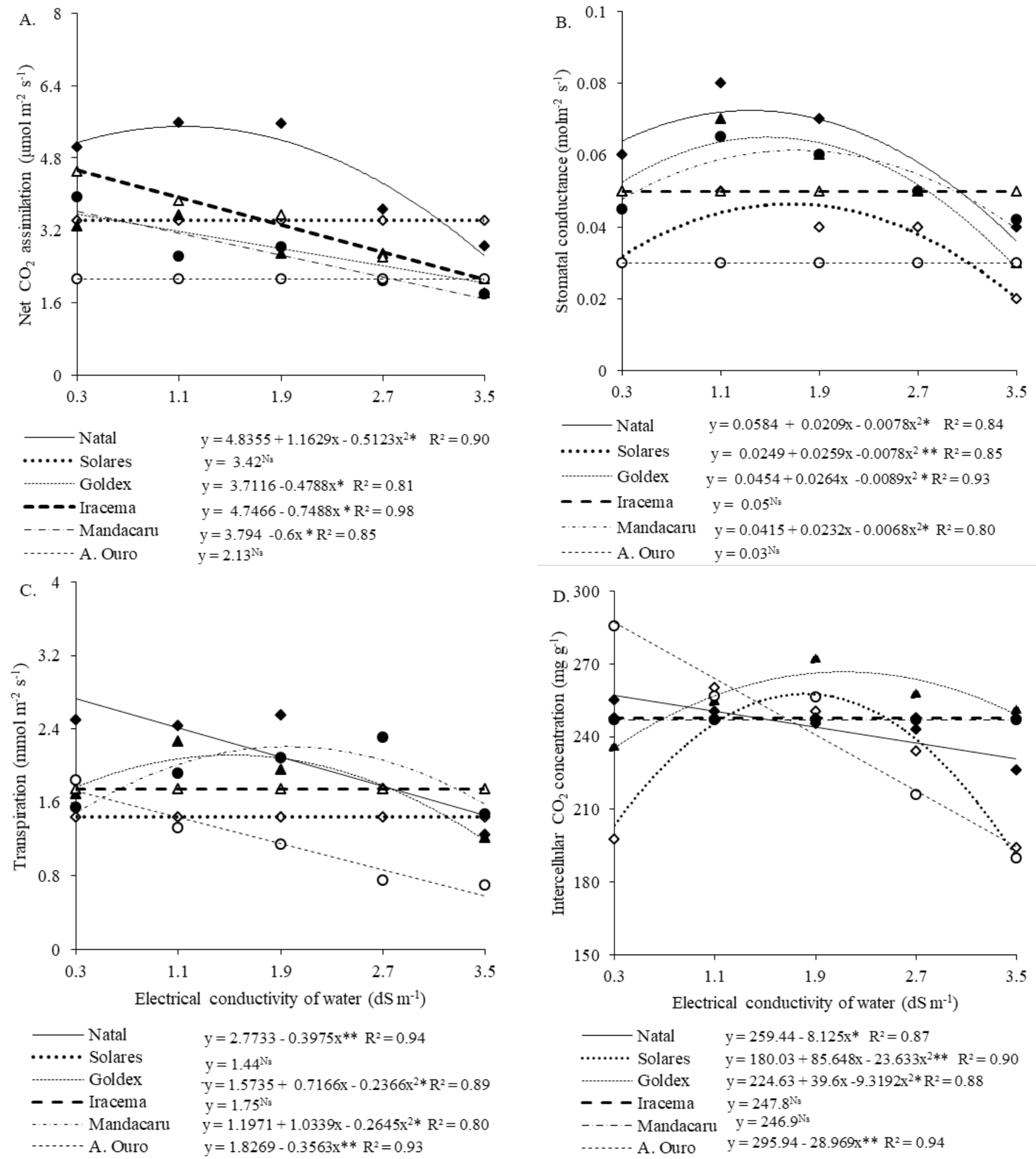

Figure 1. Net $\mathrm{CO}_{2}$ assimilation $(A)$, stomatal conductance $(B)$, transpiration (C) and intercellular $\mathrm{CO}_{2}$ concentration (D) in seedlings of melon cultivars $(\diamond)$ Natal, $(\diamond)$ Solares, $(\boldsymbol{\Delta})$ Goldex, $(\Delta)$ Iracema, $(\bullet)$ Mandacaru and $(\circ)$ Amarelo Ouro irrigated using water of increasing salinity

During the process of $\mathrm{CO}_{2}$ absorption, plants inevitably lose water through the leaves, which occurs mainly through the stomata, which have mechanisms to control their degree of opening and, under stress conditions, there is a reduction, thus explaining the increased transpiration up to a certain level of salinity and subsequent reduction observed in some cultivars (Melo et al., 2017). Evaluating the physiology of melon subjected to saline conditions, Lúcio et al. (2013) observed reductions in transpiration, stomatal conductance and net
$\mathrm{CO}_{2}$ assimilation with the increment in the contents of salts in irrigation water.

Increasing salinity levels linearly reduced the internal $\mathrm{CO}_{2}$ concentration $(\mathrm{Ci})$ for the cultivars Natal and Amarelo Ouro, with losses of 10.11 and $32.27 \%$ between the lowest and highest levels of electrical conductivity, respectively. In the cultivars Solares and Goldex, the Ci was increased up to electrical conductivity levels from 0.3 to 1.8 and from 0.3 to $2.3 \mathrm{dS} \mathrm{m}^{-1}$, showing increases of 26.53 and $13.04 \%$, respectively (Figure 1D). 
Despite such behavior for these cultivars (Solares and Goldex), there was no increase in net assimilation rate (photosynthesis), i.e., the increased carbon detected in the substomatal chamber and available for photosynthesis was not synthesized during the carboxylation phase (Morais et al., 2018). The cultivars Iracema and Mandacaru showed means of 247.8 and $246.9 \mathrm{mg} \mathrm{g}^{-1}$ of $\mathrm{CO}_{2}$.

Waters with higher salinity levels caused reduction in stomatal opening, limiting $\mathrm{CO}_{2}$ assimilation and transpiration in plants, and consequently reducing their photosynthetic rates (Bosco et al., 2009; Lucio et al., 2013; Melo et al., 2017). This leads to alterations in the state of thylakoid membranes of chloroplasts, which cause changes in the characteristics of the signals of fluorescence and consequently reduction in
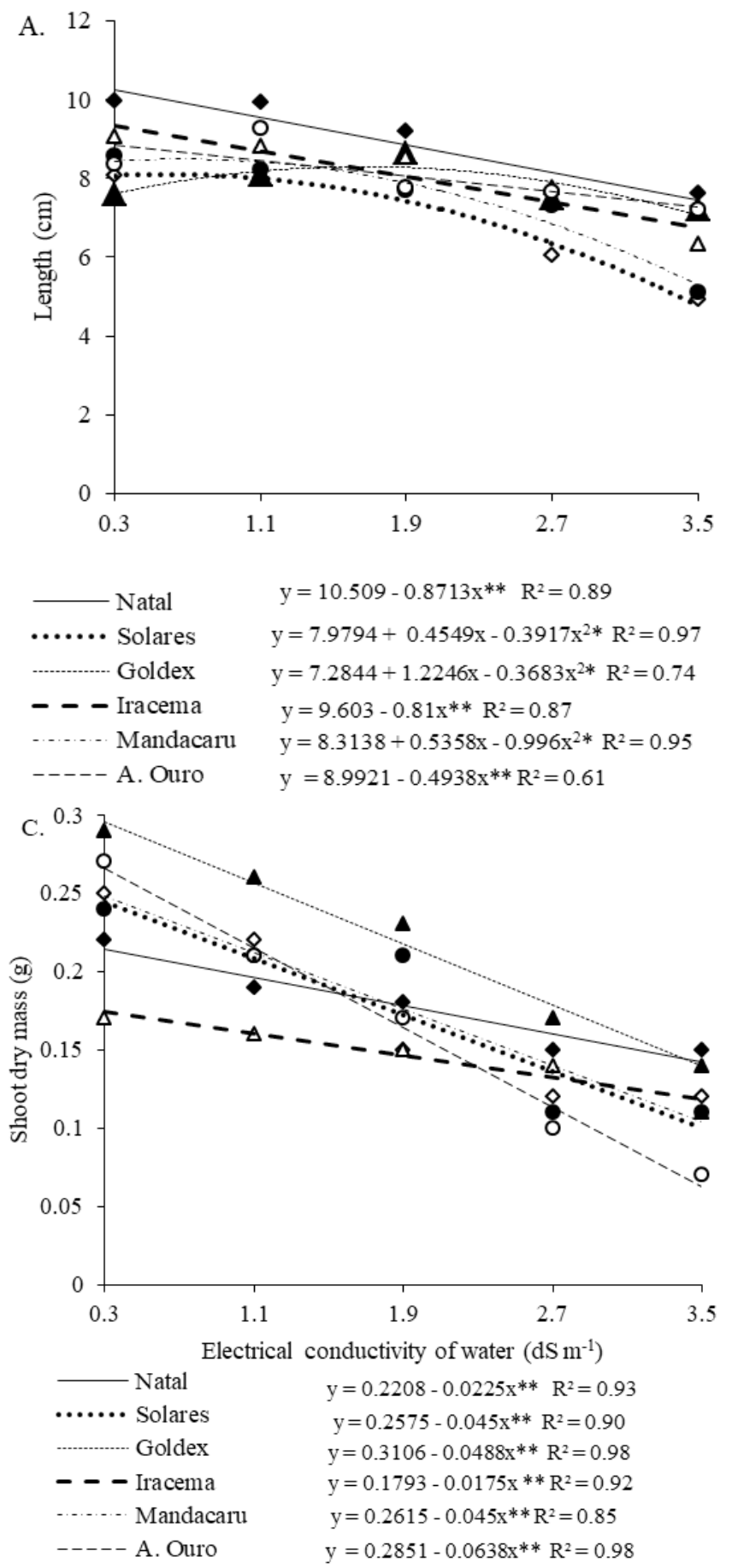

plant growth and production (Taiz et al., 2017; Sá et al., 2018; Lima et al., 2018).

Increased salinity caused linear reductions of 27.20, 27.69 and $17.86 \%$ in the stem length of the cultivars Natal, Iracema and Amarelo Ouro. On the other hand, it stimulated the growth of this variable in the cultivars Solares, Goldex and Mandacaru up to highest values of $8.11,8.30$ and $8.49 \mathrm{~cm}$. These values express increments of $0.38,8.96,0.64 \%$ in these cultivars between plants irrigated using water from $0.3 \mathrm{dS} \mathrm{m}^{-1}$ to those subjected to $0.6,1.7$ and $0.7 \mathrm{dS} \mathrm{m}^{-1}$, respectively (Figure $2 \mathrm{~A}$ ).

The inhibition of plant growth by salt stress is related to the adverse effects of the excess of salts on the ionic equilibrium, water balance, mineral nutrition and carbon metabolism

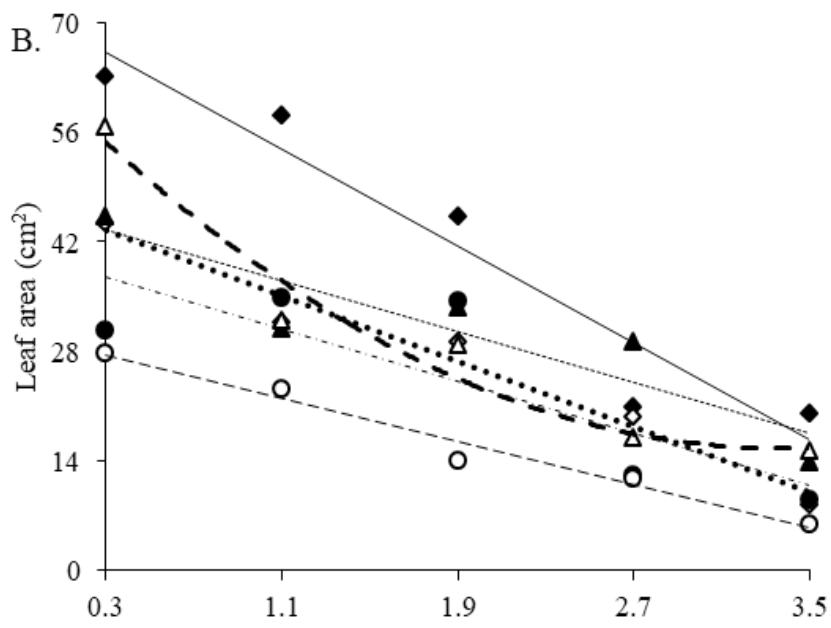

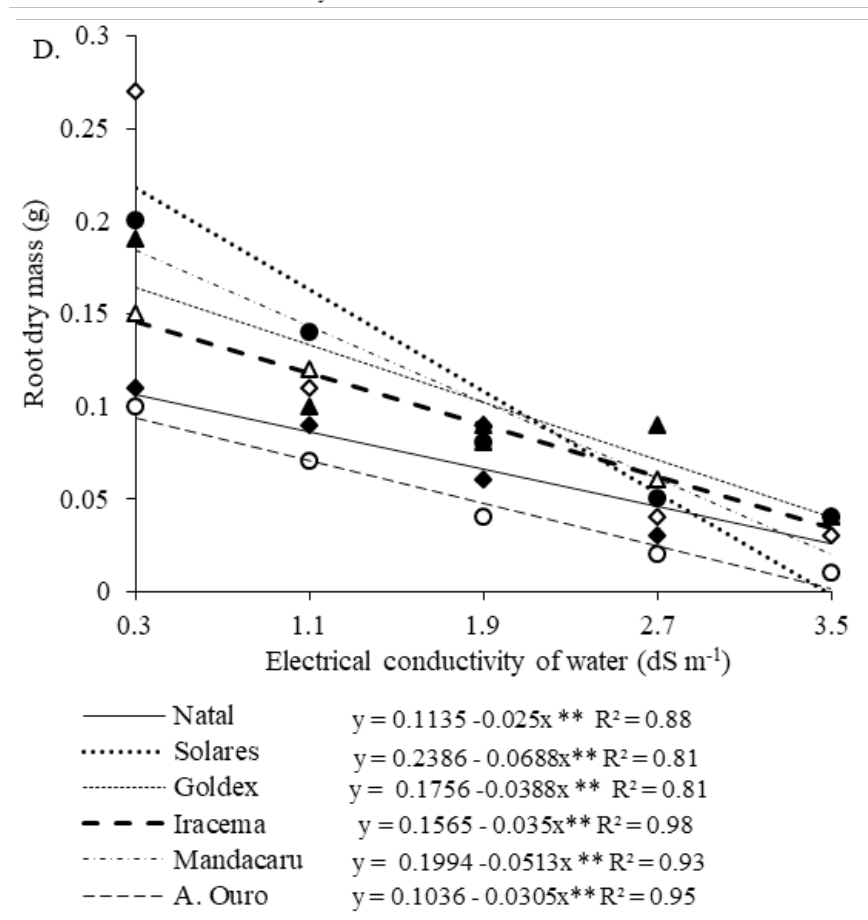

Figure 2. Length (A), leaf area (B), shoot dry mass (C) and root dry mass (D) in seedlings of melon cultivars $(\diamond)$ Natal, $(\diamond)$ Solares,

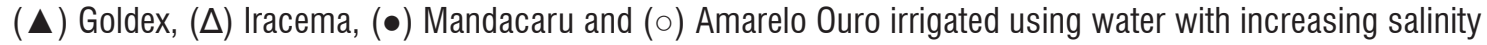


(Prisco et al., 2016). The results corroborate those of Araújo et al. (2016), who evaluated the initial growth and tolerance of the melon cultivars Gaúcho Redondo, Gaúcho Casca de Carvalho and Hales Best Jumbo to water salinity and concluded that the cultivars of the same species exhibited differences in terms of growth in height and shoot dry biomass.

Increasing irrigation water salinity negatively affected leaf expansion in the seedlings of melon cultivars (Figure 2B). The cultivars which showed lower reductions between lowest and highest levels of electrical conductivity, were Goldex (59.69\%), Mandacaru (70.84\%), Iracema (71.28\%) and Natal (74.63\%), whereas Solares and Amarelo Ouro showed greater reductions, 77.24 and $79.94 \%$, respectively.

According to Lopes et al. (2017), the phase of production of melon seedlings is one of the most harmed by the effects of irrigation water salinity. The reductions must be responses to the increase in substrate salinity caused by daily irrigation with saline waters, as reported by Lima Neto et al. (2016) in seedlings of papaya (Carica papaya) cv. Golden and by Oliveira et al. (2017) in seedlings of jackfruit (Artocarpus heterophyllus) 'Mole' variety, irrigated with saline waters. Similar situation was presented by Aragão et al. (2009), who found that water salinity caused inhibition of leaf area in the melon cultivars AF682, Gaúcho and Sancho.

Continuous daily addition of water with high contents of soluble and toxic salts in the substrate for growth and development of plants can cause water deficit, nutritional imbalance and toxicity by specific ions. These effects lead to inhibition in plant growth, in which shoots and leaves (growth and expansion) are the plant parts most affected by salt stress (Parihar et al., 2015; Taiz et al., 2017).

The increase in irrigation water salinity reduced dry mass accumulation in the melon seedlings. The shoot dry mass of the melon cultivars (Figure 2C) decreased linearly as irrigation water salinity increased; the cultivars Natal, Iracema and Goldex were the most tolerant $(10.2,9.76,15.71 \%$ of reduction per unit increase in salinity) and the cultivars Solares, Mandacaru and Amarelo Ouro were the most sensitive (17.48, 17.21 and $22.32 \%$ of reduction per unit increase in irrigation water salinity). The root dry mass of melon seedlings decreased with the increase of salts in the irrigation water by $75.47,97.85$, $75.72,76.71,89.21$ and $96.87 \%$ in the respective cultivars Natal, Solares, Goldex, Iracema, Mandacaru and Amarelo Ouro comparing waters of 0.3 and $3.5 \mathrm{dS} \mathrm{m}^{-1}$ (Figure 2D).

With the reduction of growth in plants under saline conditions, it is possible to infer a reduction in biomass production (Aragão et al., 2009). These results corroborate those of Lopes et al. (2017), who studied melon varieties, Melão Gaúcho Casca de Carvalho and Hales Best Jumbo, subjected to different levels of salinity and also found reductions of dry mass accumulation in the plants.

Highest salinity tolerance index was observed in the cultivar Natal, which maintained relative biomass yield of about $62.24 \%$ at water salinity of $3.5 \mathrm{dS} \mathrm{m}^{-1}$, thus standing out as tolerant to salinity of $2.5 \mathrm{dS} \mathrm{m}^{-1}$ for showing $75 \%$ yield during the stage of seedling. The cultivars Solares, Goldex, Iracema and Mandacaru were considered as moderately sensitive, because they showed yield of approximately $75 \%$ at salinity of $1.5 \mathrm{dS} \mathrm{m} \mathrm{m}^{-1}$. Conversely, the cultivar Amarelo Ouro was indicated as the most sensitive with only $21.01 \%$, relatively, at $3.5 \mathrm{dS} \mathrm{m}^{-1}$, with relative yield of $75 \%$ at salinity of $0.8 \mathrm{dS} \mathrm{m} \mathrm{m}^{-1}$ (Figure 3 ).
Araújo et al. (2016) also observed divergence in the aspect of tolerance to water salinity in the initial growth of melon cultivars, where Gaúcho Casca Carvalho was moderately sensitive to salinity of $3.0 \mathrm{dS} \mathrm{m}^{-1}$, while Gaúcho Redondo was characterized as the most sensitive, with relative yield of $48.46 \%$ under the same irrigation water, i.e., cultivars of a same species showed different behaviors with respect to tolerance to salinity.

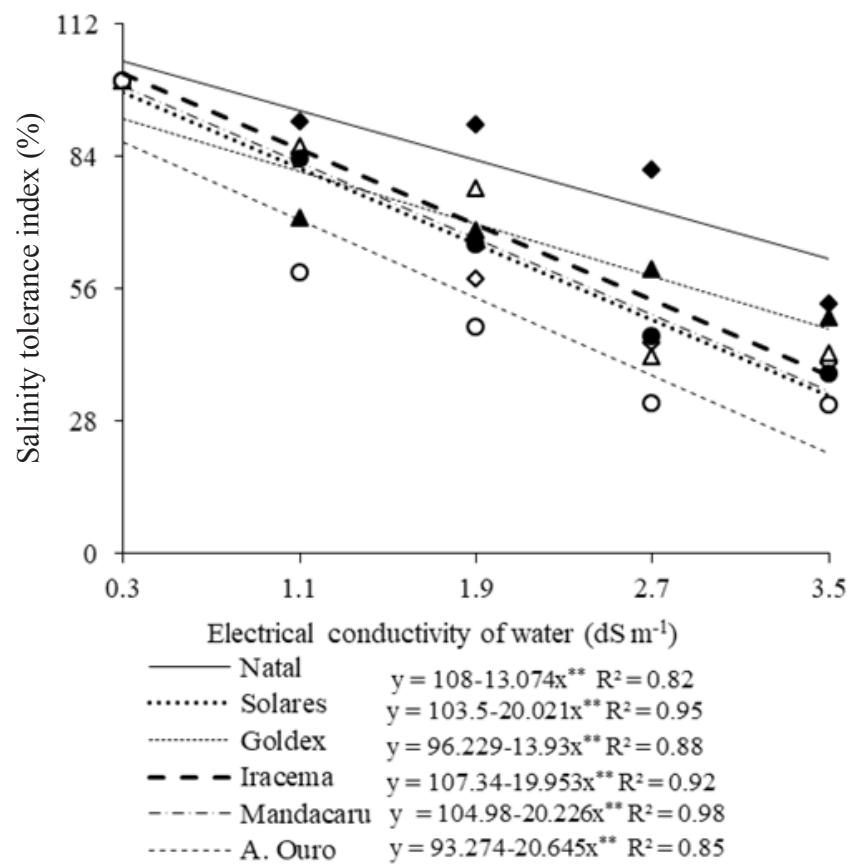

Figure 3. Salinity tolerance index of seedlings of melon cultivars $(\diamond)$ Natal, $(\diamond)$ Solares, $(\Delta)$ Goldex, $(\Delta)$ Iracema, $(\bullet)$ Mandacaru and $(\circ)$ Amarelo Ouro irrigated using water of increasing salinity

\section{Conclusions}

1. The increase in irrigation water salinity inhibits the growth, dry mass accumulation and physiological processes of the melon cultivars.

2. Water salinity harms the gas exchanges of melon seedlings in different ways among the cultivars, and the cultivar Natal was less compromised in terms of photosynthesis.

3. Waters with salinity of up to $2.5 \mathrm{dS} \mathrm{m}^{-1}$ are recommended for irrigation of melon plants cv. Natal, whereas waters of $1.5 \mathrm{dS} \mathrm{m}^{-1}$ can be used for the cultivars Solares, Goldex, Iracema and Mandacaru, and waters of $0.8 \mathrm{dS} \mathrm{m}^{-1}$ can be used for the cultivar Amarelo Ouro in the production of seedlings.

\section{Acknowledgments}

To the Coordination for the Improvement of Higher Education Personnel (CAPES) for granting the scholarship to the first author. To the company Agropecuária Vitamais Eireli for providing the seeds.

\section{Literature Cited}

Akrami, M.; Arzani, A. Physiological alterations due to field salinity stress in melon (Cucumis melo L.). Acta Physiologiae Plantarum, v.40, p.1-14, 2018. https://doi.org/10.1007/s11738-018-2657-0 
Alvares, C. A.; Stape, J. L.; Sentelhas, P. C.; Gonçalves, J. L. de M.; Sparovek, G. Köppen's climate classification map for Brazil. Meteorologische Zeitschrift, v.22, p.711-728, 2013. https://doi. org/10.1127/0941-2948/2013/0507

Aragão, C. A.; Santos, J. S.; Queiroz, S. O. P.; França, B. Avaliação de cultivares de melão sob condições de estresse salino. Revista Caatinga, v.22, p.161-169, 2009.

Arantes, A. de M.; Donato, S. L. R.; Siqueira, D. L.; Coelho, E. F.; Silva, T. S. Gas exchange in different varieties of banana prata in semiarid environment. Revista Brasileira de Fruticultura, v.38,p.1-12, 2016. https://doi.org/10.1590/0100-29452016600

Araújo, E. B. G.; Sá, F. V. da S.; Oliveira, F. A. de; Souto, L. S.; Paiva, E. P. de; Silva, K. do N.; Mesquita, E. F. de; Brito, M. E. B. Crescimento inicial e tolerância de cultivares de meloeiro à salinidade da água. Revista Ambiente Água, v.11, p.462-470, 2016.

Bosco, M. R. de O.; Oliveira, A. B. de; Hernandez, F. F. F.; Lacerda, C. F. de. Efeito do $\mathrm{NaCl}$ sobre o crescimento, fotossíntese e relações hídricas de plantas de berinjela. Revista Ceres, v.56, p.296-302, 2009.

Carmo, G. A. do; Oliveira, F. R. A. de; Medeiros, J. F. de; Oliveira, F. de A. de; Campos, M. de S.; Freitas, D. C. de. Teores foliares, acúmulo e partição de macronutrientes na cultura da abóbora irrigada com água salina. Revista Brasileira de Engenharia Agrícola e Ambiental, v.15, p.512-518, 2011. https://doi.org/10.1590/S1415-43662011000500012

Costa, A. R. F. C. da; Medeiros, J. F. de; Porto Filho, F. de Q.; Silva, J. S. da; Costa, F. G. B.; Freitas, D. C. de. Produção e qualidade de melancia cultivada com água de diferentes salinidades e doses de nitrogênio. Revista Brasileira de Engenharia Agrícola e Ambiental, v.17, p.947954, 2013. https://doi.org/10.1590/S1415-43662013000900006

Donagema, G. K.; Campos, D. V. B.; Calderano, S. B.; Teixeira, W. G.; Viana, J. H. M. (org.). Manual de métodos de análise de solo. 2.ed. Rio de Janeiro: Embrapa Solos, 2011. 230p.

Ferreira, D. F. Sisvar: A computer statistical analysis system. Ciência e Agrotecnologia, v.35, p.1039-1042, 2011. https://doi.org/10.1590/ S1413-70542011000600001

Freire, J. L. de O.; Dias, T. J.; Cavalcante, L. F.; Fernandes, P. D.; Lima Neto, A. J. de. Rendimento quântico e trocas gasosas em maracujazeiro amarelo sob salinidade hídrica, biofertilização e cobertura morta. Revista Ciência Agronômica, v.45, p.82-91, 2014. https://doi.org/10.1590/S1806-66902014000100011

Freitas, L. D. A.; Figueiredo, V. B.; Porto Filho, F. de Q.; Costa, J. C. da; Cunha, E. M. da. Crescimento e produção do meloeiro cultivado sob diferentes níveis de salinidade e nitrogênio. Revista Brasileira de Engenharia Agrícola e Ambiental, v.18 p.20-26, 2014. https:// doi.org/10.1590/1807-1929/agriambi.v18nsupps20-s26

IBGE - Instituto Brasileiro de Geografia e Estatística. Censo agropecuário 2017. Disponível em: <www.ibge.com.br>. Acesso em: Jul. 2018.

Lima, G. S. de; Dias, A. S.; Souza, L. de P.; Sá, F. V. da S.; Gheyi, H. R.; Soares, L. A. dos A. Effects of saline water and potassium fertilization on photosynthetic pigments, growth and production of West Indian cherry. Revista Ambiente \& Água, v.13,p.1-12, 2018. https://doi.org/10.4136/ambi-agua.2164

Lima Neto, A. J. de; Cavalcante, L. F.; Mesquita, F. de O.; Souto, A. G. de; Santos, G. P. dos; Santos, J. Z. dos; Mesquita, E. F. Papaya seedlings irrigation with saline water in soil with bovine biofertilizer. Chilean Journal of Agricultural Research, v.76, p.236242, 2016. https://doi.org/10.4067/S0718-58392016000200014

Lopes, M. A. C.; Muniz, R. V. S.; Alves, S. S. V.; Ferreira, A. C.; Sá, F. V. S.; Silva, L. A. Água salina e substratos no crescimento inicial do meloeiro. Irriga, v.22, p.469-484, 2017. https://doi.org/10.15809/ irriga.2017v22n3p469-484
Lúcio, W. da S.; Lacerda, C. F. de; Mendes Filho, P. F.; Hernandez, F. F.; Neves, A. L. R.; Gomes-Filho, E. Crescimento e respostas fisiológicas do meloeiro inoculado com fungos micorrízicos arbusculares sob estresse salino. Semina: Ciências Agrárias, v.34, p.1587-1602, 2013. https://doi.org/10.5433/1679$0359.2013 \mathrm{v} 34 \mathrm{n} 4 \mathrm{p} 1587$

Medeiros, D. C. de; Medeiros, J. F. de; Barbosa, M. A. G.; Queiroga, R. C. F.; Oliveira, F. de A.; Freitas, W. E. de S. Crescimento do melão Pele de Sapo, em níveis de salinidade e estágio de desenvolvimento da planta. Revista Brasileira de Engenharia Agrícola e Ambiental, v.16, p.647-654, 2012. https://doi. org/10.1590/S1415-43662012000600009

Melo, H. F. de; Souza, E. R. de; Duarte, H. H. F.; Cunha, J. C.; Santos, H. R. B. Gas exchange and photosynthetic pigments in bell pepper irrigated with saline water. Revista Brasileira de Engenharia Agrícola e Ambiental, v.21, p.38-43, 2017. https:// doi.org/10.1590/1807-1929/agriambi.v21n1p38-43

Morais, P. L. D. de; Dias, N. da S.; Oliveira, A. M. de; Sousa Neto, O. N. de; Sarmento, J. D. A.; Gonzaga, M. I. S. Effects of nutrient solution salinity on the physiological performance of melon cultivated in coconut fiber. Revista Caatinga, v.31, p.713-718, 2018. https://doi. org/10.1590/1983-21252018v31n321rc

Nascimento, I. B. do; Farias, C. H. A.; Silva, M. C. C.; Medeiros, J. F. de; Espínola Sobrinho, J.; Negreiros, M. Z. de. Estimativa da área foliar do meloeiro. Horticultura Brasileira, v.20, p.555-558, 2002. https://doi.org/10.1590/S0102-05362002000400009

Oliveira, F. I. F. de; Souto, A. G. de L.; Cavalcante, L. F.; Medeiros, W. J. F. de; Bezerra, F. T. C.; Bezerra, M. A. F. Quality of jackfruit seedlings under saline water stress and nitrogen fertilisation. Semina: Ciências Agrárias, v.38, p.2337-2350, 2017. https://doi. org/10.5433/1679-0359.2017v38n4SUPLp2337

Parihar, P.; Singh, S.; Singh, R.; Singh, V. P.; Prasad, S. M. Effect of salinity stress on plants and its tolerance strategies: A review. Environmental Science and Pollution Research, v.22, p.4056-4075, 2015. https://doi.org/10.1007/s11356-014-3739-1

Pereira, F. A. de L.; Medeiros, J. F. de; Gheyi, H. R.; Dias, N. da S.; Preston, W.; Vasconcelos, C. B. e L. Tolerance of melon cultivars to irrigation water salinity. Revista Brasileira de Engenharia Agrícola Ambiental, v.12, p.846-851, 2017. https://doi.org/10.1590/18071929/agriambi.v21n12p846-851

Prisco, J. T.; Gomes Filho, E.; Miranda, R. de S. Physiology and biochemistry of plants growing under salt stress. In: Gheyi, $\mathrm{H}$. R.; Dias, N. da S.; Lacerda, C. F. de; Gomes Filho, E. Manejo da salinidade na agricultura: Estudos básicos e aplicados. 2.ed. Fortaleza: INCTSal, 2016. Chap.12, p.163-180.

Rhoades, J. D.; Kandiah, A.; Mashali, A. M. Uso de águas salinas para produção agrícola. Campina Grande: UFPB, 2000. 117p.

Sá, F. V. S.; Gheyi, H. R.; Lima, G. S.; Paiva, E. P.; Moreira, R. C. L.; Silva, L. A. Water salinity, nitrogen and phosphorus on photochemical efficiency and growth of west indian cherry. Revista Brasileira de Engenharia Agrícola e Ambiental, v.22, p.158-163, 2018. https:// doi.org/10.1590/1807-1929/agriambi.v22n3p158-163

Silva, J. E. S. B. da; Matias, J. R.; Guirra, K. S.; Aragão, C. A.; Araujo, G. G. L. de; Dantas, B. F. Development of seedlings of watermelon cv. Crimson Sweet irrigated with biosaline water. Revista Brasileira de Engenharia Agrícola e Ambiental, v.19, p.835-840, 2015. https:// doi.org/10.1590/1807-1929/agriambi.v19n9p835-840

Taiz, L.; Zeiger, E; Moller, I. M.; Murphy, A. Fisiologia e desenvolvimento vegetal. 6.ed. Porto Alegre: Artmed, 2017. 918p. 